\title{
The Trajectory Of Balls
}

\section{Major-General P. Anstruther C.B.}

To cite this article: Major-General P. Anstruther C.B. (1861) The Trajectory Of Balls, Royal United Services Institution. Journal, 5:18, 309-321, DOI: 10.1080/03071846109416752

To link to this article: http://dx.doi.org/10.1080/03071846109416752

\section{册Published online: 25 Sep 2009.}

Submit your article to this journal $\pi$

Џll Article views: 2

Q View related articles $₫$ 
Friday, May 24th, 1861

Col. P. J. YORKE, F.R.S. in the Chair.

\section{THE TRAJECTORY OF BALLS.}

\section{By Major-General P. Axstretmen, C.B., II.MI. MIndras Artillery.}

\section{Preface.}

Extract from "Straith's MEmoir of Artillery," pp. 81, 82 : "Dr. Gregory, in his Lectures upon Gumnery, observes, on the difference between the times enplojed by a ball in ascending, and descending rertically throngls the same space: If a 24-pound iron ball were projected rertically upwards, with a relocity of 2000 feet per second, it rrould ascend to the height of 6424 feet before its upward motion was extinguished, and it would pass orer that space in less than 912 seconds. (This is computed in 'Hutton's Mathematics,' rol. 3.) It might, on a cursory view of the subject, be supposed that the circumstances of the descent ronld be analogous to those of the ascent, but in an inverted order: and so they would in a nonresisting medium; but in the air the case is videly different. After the ball had descended 2700 fect, the resistance of the air wonld be equal to the weight of the ball, there would remain no further cause of acceleration, nnd the ball would descend uniformly with its terminal relocity (that is, the greatest velocity which a heary body can acquire when falling in the air), which does not exced 419 feet per second. It would require, therefore, $\frac{6424-2700}{419}$, or 6 seconds, to descend the remaining 3724 feet, in addition to the time, abont 10 seconds, which had been occupied in descending through the first 2700 feet; so that, in this instance, the time of descent mould be about double that of ascent. In all cases where the projectile relocity exceeds 300 or 400 feet, the time of descent will exceed that of ascent; and their difference is greater the more the initial relocity exceeds that limit."

1. $\Lambda$ s we are unable to procure a copy of Dr. Gregory's Lectures on Gumnery, we must content ourselves with an extract, quoted from Hector Straith's Memoir on Artillery, vide Preface.

Speaking of a ball fired rertically upwrards, he says, after detailing the particulars of the initial velocity, time of niglit, \&e. \&e. "so that, in this case, the time of descent would be about donble that of ascent."

2. These are the words of a professor at the Military Seminary of Addiscombe, quoting those of the Professor of Mathematics at the Royal Mrilitary Academy of Woolwich; we may therefore safely infer that this was what the greater portion of Her Majesty's Artillery learned as part of the science of gunnery. 
3. Believing that, as in the case supposed above, so in any case of a ball's being fired upwards, the time of ascent and the time of descent must of necessity be exactly equal, it is obvionsly on imperative duty to protest in the most public manner in our power against the contiuued training up of our young officers in a course of error.

4. By the first law of motion we learn that "A body in motion, not acted upon by any extemal force, will move in a straight line and with a uniforn relocity."

Suppose a 24-pound iron ball projected rertically upwards with relocity $\mathrm{V}$, it rould, in any time $\mathrm{T}$, ascend in a straight line to a distance equal to $T V$, the number of feet per- second de-

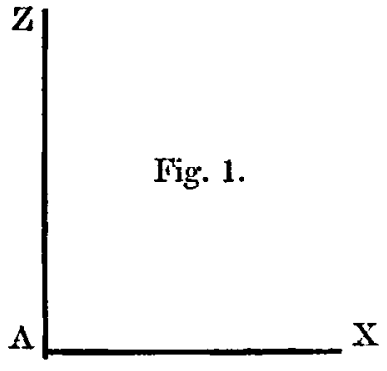
noted by $V$ multiplied by the number of seconds denoted by $T$, if it were not acted upon by any external force whaterer. Let A X represent a horizontal plane, and suppose the 24-pounder gun placel at $A$ and fired vertically upwards, the ball would, in the time $T$, go rertically upwards to a distance equal to $\mathrm{TV}$; let the line $\mathrm{A} Z$ forming a right angle with $A \mathbf{X}$ represent the measure and direction of the path of the ball if not acted upon by any external force.

5. But the ball does not go from $A$ to $Z$ in the time $\mathrm{T}$; it is seen to ga part of the rray and to retum, striking the plane $\mathrm{AX}$ at the expiry of the time $\mathrm{T}$. Dr. Gregory gires for the time of ascent "less than $9 \cdot 5$ seconds," and he gives a timo of "about 10 seconds" for one part of the descent, and another of " 6 seconds" for the other part of the descent; a total of 25.5 seconds for the whöle time of flight of this 24-pound ball fired rertically uptrards.

6. It follows, therefore, that the ball has been acted nyon by some external force duing its time of flight, and a rery short reflection gires us the certainty that it has been acted upon by tro, and only two, extemal forces; these are,

1. The resistance of the atmosphere, and,

2. The force of gravity.

These tro we shall consider separately.

7. The first of the two, the resistance of the atmosphere, can only act by diminishing the length of $\Lambda \mathrm{Z}$; it cannot take it out of the line of direction given to it, nor can this force in any degree whatever tend to bring the ball back to $A$, as we see the ball does come, back in 25.5 seconds. Therefore there is, somewhere or other on the line $A Z, n$ point $Y$, nt which the ball rould hare arrived in the time 25.5 seconds if acted upón by no other external force, but by this force alone; the portion of $A Z$ which is between $Z$ and $\mathrm{Y}$ is the measure of the retardation produced A $\mathrm{X}$ by the resistance of the atmosphere.

8. The remaining portion of $A \mathrm{Z}$, which is between $A$ and $Y$, is the measure of the effect of the force of grarity rpon 
this ball in motion from $A$ towards $Z$ during $25 \cdot 5$ seconds of time, and we proceed to consider this mith the assistance of the second lam of motion, from which we leam, that, "When any force acts upon a body in motion, the change of motion which it produces is the same in magnitude and direction as the effect of the force upon the body at rest." That is to sas, when the force of gravity alone acts upon this 24-pound ball in motion from $A$ tomards $Y$, the change of motion which it produces is the same in magnitude and direction as the effect of the force of grarity upon the 24-pound ball at rest.

9. Noif what is the effect of the foree of gravity upon a 24-pound ball suffered to fall from a state of rest, during the giren time, $25 \cdot 5$ seconds? What is the fall by grarity during $25^{\circ} 5$ seconds? We can answer this readily; it is $25 \cdot 5^{2} \times 13.75=8940.9375$ feet, say 8911 feet. Dr. Giregory seems to have thought that the ball was not opposed by gravity until it had culminated; but this is eridently an error. The ball will fall by gravity, from a state of rest, through 8941 feet in $25 \cdot 5$ seconds of time, acquiring thereby relocity $\mathrm{V}$; therefore this is the exact measure of the heiglit to which it would have ascended in $25 \cdot 5$ seconds of time, if fired with initial velocity $V$, and if not opposed by grarity. We must therefore now determine the ralue of $V$, which is not difficult.

10. If we deduct the fall for $25 \cdot 49$ seconds from that for $25 \cdot 50$, the difference will give the space described by the ball in the last hundredth part of a second of its fall. It is as follows, riz.:-

$25 \cdot 50$ seconds, $25 \cdot 50 \Omega \times 13 \cdot 750=8940 \cdot 9375000$ feet.

$25 \cdot 10 \quad \# 25 \cdot 49^{\circ} \times 13 \cdot 751=8931 \cdot 5761151$ feet.

$A$ difference of 0.01 seconds and 6.3613849 feet,

Showing a relocity of $636 \cdot 13849$ feet per second $=V$.

11. If an initial relocity of 2000 feet is required to give $25 \cdot 5$ seconds time of flight to a ball fired rertically uptrards, an initial relocity of $2000 \sqrt{ } 2$ must be necessary to give the same ball at $45^{\circ}$ elevation the same time of flight, so that to range at $45^{\circ}$, with 25.5 seconds of flight, the initial relocity must be $2828^{\circ}$. Now Sir Howard Douglas tells us that at Landguard Fort (in 1806) the shell of 200lbs. with a charge of 10lbs. did range 2960 yards in 25.3 seconds at $45^{\circ}$ elevation. Did a charge of one-tenth of the shot's reight gire a relocity of 2828.4 feet per second? Our calculation makes the range twenty yards longer in threetenths of a second more time, and the relocity $036 \cdot 1385 \sqrt{ } 2$ or 900 feet per second. Is the relocity gained by using a charge of one-tenth of the shot's weight more likely to be 2828 feet, or 900 feet?

12. The Washington experiments, p. 47, prove that with a long gun, 32 -pounder, the relocities gained were, with

0.333 of the shot's weight, 1691 feet per second.

$\begin{array}{llllll}0.25 & " & " & 1570 & " & \text { ", } \\ 0.2 & " & " & 1462 & " & ", \\ 0.166 & " & " & 1396 & " & ", \\ 0.125 & " & & 1218 & " & \end{array}$

Ours of 0.1 may be corrtet, as 900 ; but how can Dr. Gregory's of 2828 ?

13. Will any amount of porder gire any cast-iron ball a velocity of 2828 , or even of 2000 feet? The French table giren in page 420 of the 
Aille-Mémoire gires relocity 1798,1791 , and 1732 , as the result of half the shot's weight, and the experiments show that a further increase of charge would not hare given any perceptible increase of the velocity. That table makes one-tenth of the shot's weight give 1004 feet, 974.5 feet, or 1013 feet from guns; we say 900 feet from mortars.

14. We shall now leave Dr. Gregory, and tum to Dr. Cape, who in his "Course of Mathematics" gires the following example on the law of gravity, vol. 2, page 216 :-

"An arrow shot perpendicularly upwards from a bow, retumed again in 10 seconds; required the velocity of projection, and the height to what it rose?

"Ans.-Velocity 161; height $402 \cdot 5$ feet."

15. Negutur. If the fall by grarity were, as held by Dr. Capc, in any time, $t$, equal to the square of the time multiplied by $16^{*} 1$, then the height and velocity would be exactly double that given by Dr. Cape. The rising and falling of the ball would be, in that case, as is shown in the following table:-

Flight, 10 Scconds.

\begin{tabular}{|c|c|c|c|c|}
\hline \multirow{2}{*}{$\begin{array}{c}\text { Seconds } \\
\text { of } \\
\text { Time. }\end{array}$} & \multicolumn{2}{|c|}{ Ascent. } & \multirow{2}{*}{$\begin{array}{l}\text { Descent } \\
\text { by } \\
\text { Gravity. }\end{array}$} & \multirow{2}{*}{$\begin{array}{l}\text { Ifelght at } \\
\text { each } \\
\text { period of } \\
\text { Time. }\end{array}$} \\
\hline & Gradual. & Camulative. & & \\
\hline 1 & $305 \cdot 9$ & 305.0 & $16 \cdot 1$ & $289 \cdot 8$ \\
\hline 2 & $273+7$ & $549 \cdot 6$ & $64 \cdot 4$ & $515 \cdot 2$ \\
\hline 3 & $241 \cdot 5$ & $821 \cdot 1$ & $144 \cdot 9$ & $676 \cdot 2$ \\
\hline 4 & $209 \cdot 3$ & $1030 \cdot 4$ & $257 \cdot 6$ & $772 \cdot 8$ \\
\hline 5 & $177 \cdot 1$ & $1207 \cdot 5$ & $402 \cdot 5$ & $805 \cdot 0$ \\
\hline 6 & $144 \cdot 0$ & $1352 \cdot 4$ & $579 \cdot 6$ & 772.8 \\
\hline 7 & $112 \cdot 7$ & $1465 \cdot 1$ & 788.0 & $676 \cdot 2$ \\
\hline 8 & $80-5$ & $1545 \cdot 6$ & 1030.4 & $515 \cdot 2$ \\
\hline 9 & $48 \cdot 3$ & $1593 \cdot 0$ & $1301 \cdot 1$ & 289.8 \\
\hline 10 & $16 \cdot 1$ & $1610^{\circ} 0$ & 1610.0 & 0.0 \\
\hline
\end{tabular}

16. Of this any gentleman may convince himself by supposing the sane time of flight, but $45^{\circ}$ of elevation; then the range would be $t^{2} \times 16^{\circ} 1=$ $10^{2} \times 16 \cdot 1=1610 \mathrm{fect}$; the velocity $20 \sqrt{ } 2 \times 16.1$ or $20 \times 16 \cdot 1 V^{2}=$ $322 \sqrt{ } 2$; showing that the rertical relocity was $20 \times 16 \cdot 1=322$ feet not 161 -

17. But, to draw the true trajectory, the above law of grarity must be altered as follows :- 


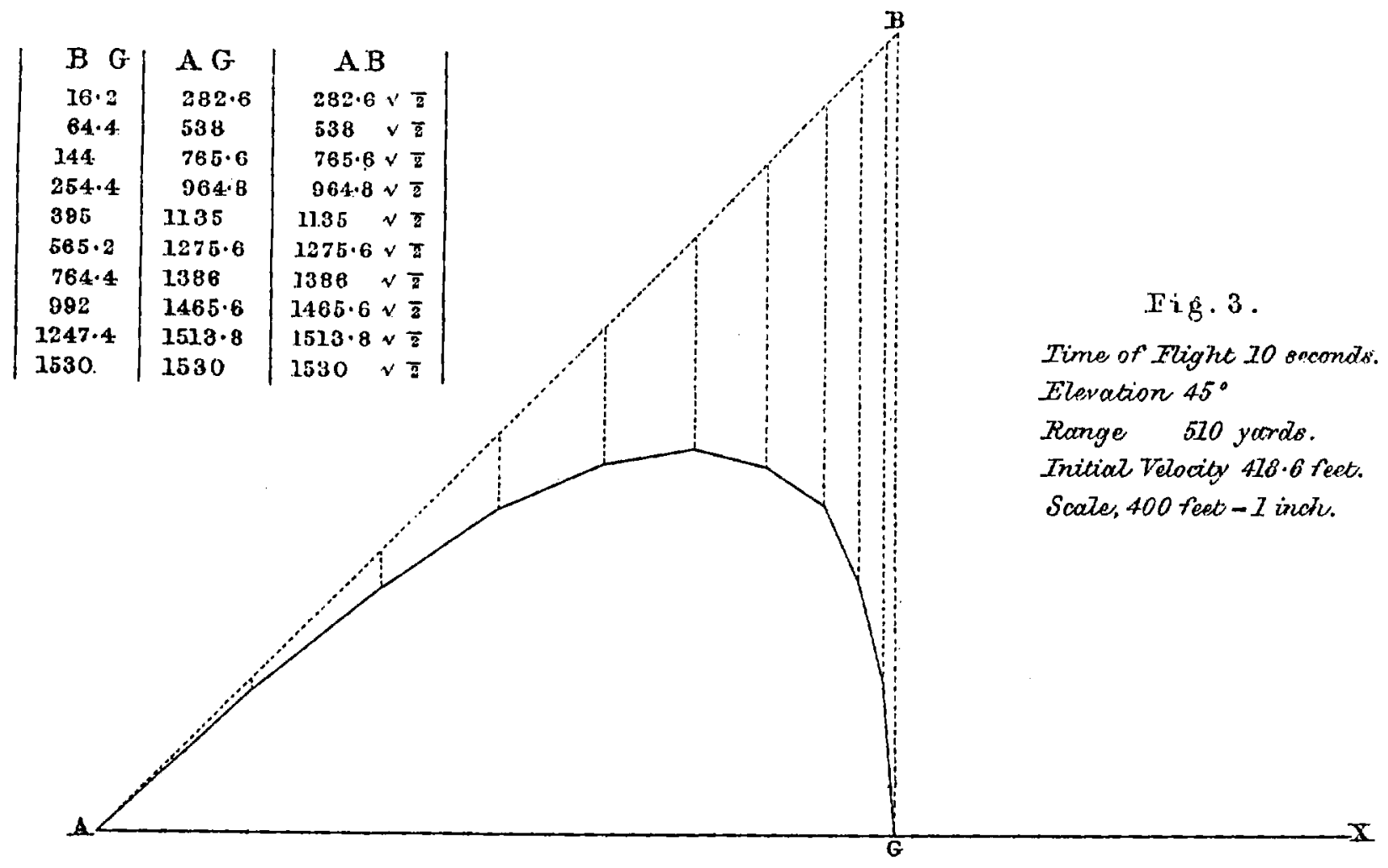




\begin{tabular}{|c|c|c|c|c|}
\hline \multirow{2}{*}{$\begin{array}{c}\text { Seconds } \\
\text { of } \\
\text { Time. }\end{array}$} & \multicolumn{2}{|c|}{ Ascent. } & \multirow{2}{*}{$\begin{array}{l}\text { Deseent } \\
\text { by } \\
\text { Gravity. }\end{array}$} & \multirow{2}{*}{$\begin{array}{l}\text { Ieight at } \\
\text { cach } \\
\text { Second of } \\
\text { Time. }\end{array}$} \\
\hline & Gradual. & Cumulative. & & \\
\hline 1 & $282 \cdot 6$ & $282 \cdot 6$ & $16 \cdot 2$ & 266.4 \\
\hline 2 & $255 \div$ & 538.0 & $61 \cdot 4$ & 473.6 \\
\hline 3 & $227 \cdot 6$ & $765 \cdot 6$ & $144 \cdot 0$ & $621 \cdot 6$ \\
\hline 4 & $199 \cdot 2$ & 964.8 & $254 \cdot 4$ & $710 \cdot 4$ \\
\hline 5 & $170 \cdot 2$ & $1135 \cdot 0$ & $395 \cdot 0$ & 740.0 \\
\hline 6 & 140.6 & $1275 \cdot 6$ & $565 \cdot 2$ & $710 \cdot 4$ \\
\hline 7 & $110 \cdot 4$ & $1386^{\circ} 0$ & 761.4 & $621-6$ \\
\hline 8 & 79.6 & $1465 \cdot 6$ & $992 \cdot 0$ & $473 \cdot 6$ \\
\hline 9 & $48 \cdot 2$ & 1513.8 & $1247 \cdot 4$ & 266.1 \\
\hline 10 & $16 \cdot 2$ & 1530.0 & $1530 \cdot 0$ & 0.0 \\
\hline
\end{tabular}

18. In Figure 3 we show the true trajectory for 10 seconds time of flight, on a scale of 400 feet to an inch, the eleration being $45^{\circ}$. It is very simple, and obriously true. It is thus constructed: Draw a rightangled triangle, $\mathrm{A} \mathrm{B} G$, in which the angles are $45^{\circ}, 45^{\circ}$, and $90^{\circ}$. Then $\Lambda G$ must represent the rnnge, and $\mathbb{B} G$ the fall by grarity for 10 seconds. On B G mark off the fall for 9 seconds, $1247 \cdot 4$ feet, and draw a horizontal line. Its intersection with $\Lambda \mathrm{G}$ will mark the portion of A G through which, if not acted upon by grarity, the ball would hare passed in the first of the ten seconds of its flight. Let fall a perpendicular, 16.1 feet in length, and its lower extremity will mark the place of the ball at the expiry of the first of the 10 seconds. In like manner we mark the fall for $8,7,6,5,4,3,2$, and 1 sceonds, and draw horizontal lines, which will diride $\Lambda \mathrm{G}$ in proportion, as shown in our para. 17. The column marked "Cumulative Ascent" shows the distance from $A$, measured vertically on $\Lambda \mathrm{G}$. Therefore the distances are $282 \cdot 6 \sqrt{ } 2,538 \sqrt{ } 2$, $765.6 \sqrt{ } 2,964.8 \sqrt{ } 2,1135 \sqrt{ } 2,1275 \cdot 6 \sqrt{ } 2,1386 \sqrt{ } 2,1465.6 \sqrt{ } 2$, $1513.8 \sqrt{2}$, and $1530 \sqrt{2}$-which is the whole length of $A \mathrm{G}$.

19. This ascent would be the, same at any other elevation as at $45^{\circ}$. If gravity were not acting upon the ball it would, at any elerntion, go $1513.8,2$ feet in 9 seconds. Now suppose that gravity dors act, we see that the fall by grarity is 1247.1 feet for 9 seconds. Then we find the range thus : $A \mathrm{~B}^{2}-\mathrm{B} \mathrm{G}^{2}=\Lambda \mathrm{G}^{2}$. But the portion of $\Lambda \mathrm{B}$ for 9 seconds is $1513.8 \sqrt{ } 2$, and $B G$ is 1247.4 ; therefore $\Lambda G=1739.87$ feet, the range for this time of flight, which is 70 yards further than the range at $45^{\circ}$. The eleration to give this is easily found, as $1513 \cdot 8 \sqrt{2: 90^{\circ}}:$ : $1247 \cdot 4: 28^{\circ} 16^{\prime} 10^{\prime \prime}$, the required eleration.

20. The initial relocity for 10 seconds of flight at $45^{\circ}$ is $296 \sqrt{ } 2$, o1 $418 \cdot 6$ feet per second; its range 510 yards. The French Table, p. 422 
of the Aile-Alémoire, gives for 9 seconds 437 yards; for $10 \frac{1}{2}$ seconds, 537 yards; therefore for 10 seconds about 500 yards-ours being 510 .

21. Supposing that, instead of firing the ball vertically upwards with initial relocity $V$, wo trere to gire a small additional charge of porder, and eleration $85^{\circ}$, the additional charge of porder being exactly that which would preserve the same time of flight. Then, the time of flight being the same, the fall by grarity mut of necessity be the same also; and: the range, being measured, will enable us to calculate the exact height tó which the ball would have ascended, if it had not been. acted upon by gravity.

22. In Figure 4, let $B$ G represent the fall by gravity in the time of

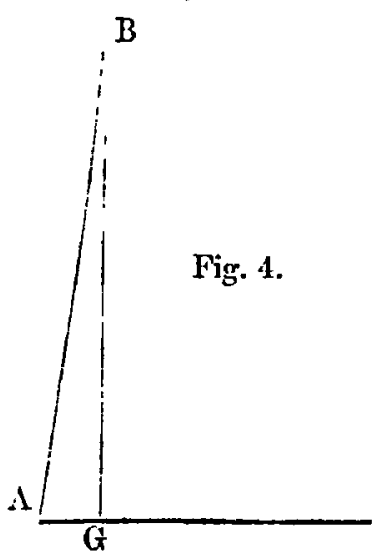
flight, whether for $25^{\circ} 5^{\prime \prime}$, as in Doctor Gregory's case, or for ten seconds, as in Doctor Cape's. Then, if we measure $A \mathrm{G}$, the range at $85^{\circ}$, we can easily calculate the exact length of $B$ G. For as $\sin .5^{\circ}: \Lambda$ G : : sin. $85^{\circ}$ : B G. Supposing that we fired with a certain charge, and found that at $85^{\circ}$ the range $A G$ was $1106 \cdot 24$ feet, then we should know that $B G=8040.9375$ feet.

23. There is no reason why we should not fire the larger 10-inch howitzer of 61 tons wcight with stich a charge as would, at $85^{\circ}$ elevation, give a range of 1106.24 feet, or 368.75 yards. Any range at this eleration would do as well; but suppose that, by chance, the range were to prove exactly $1106 \cdot 24$ feet, and that, firing the solid shot of 140lbs. weight, we made the charge of porder exactly such, that we could be certain of getting the same range, then if we were to lay the target of the electrochronoscope level on the ground, corering the spot on which by experiment mo knew the ball would fall, the ball would cut the electric wire, and we should know that the time of flight had been $25 \cdot 19097$ seconds, which we shoild call 25.5 seconds. We should then calculate the height which would give us the measure of the fall by gravity in 25.5 seconds, which tre linve hitherto never been ablo to determine.

24. Or if we fired with a very small charge at $85^{\circ}$, and finding the range to be 133.8670 feet, then placing the target of the electro-chronoscope on the spot struck, and firing again, suppose the wire to be cut in 0.99997 secouds, which we should call 10 seconds, then we should calculate B G by saying, as the sin. $5^{\circ}: 133 \cdot 8676:: \sin .85: 1529 \cdot 9997$, which we should call $\mathbf{1 5 3 0}$, and determine thence that the fall by gravity for 10 sceorids is 1530 feet, or $10^{2} \times 15.3$ feet.

25. A fow experiments of this nature with the electro-clironoscope would settle all the undetermined questions in gunnery, and render our science as certain as any of the others which have been brought to such perfection by mathematical calculations.

26. The electro-chronoscope.will for a thirtieth or fortieth part of the price of the ballistio pendulum giro us far more accurate results; the expense, after the purchase of the instrument itself, is only the pordes burnt, and we may now hope to know the real path of our projectiles. 
27. No method sppears to present itself of calculating exactly the range from the elevation, except at $45^{\circ}$, but we can calculatê the range for giren time, and then find the angle of eleration which rould give it. For example, suppose the time $20 \cdot 1$ seconds. Then B G, the fall by grarity, is $20.12 \times 14.29$ feet $=5773.3029$ feet. And $A$ B we find thus: - From $25 \cdot 5$ deduct $20 \cdot 1$; the difference is $\tilde{5} \cdot 4$.

From $\quad 8940.9375$, the fall for $25 \cdot 5$ seconds.

Take $\quad 459 \cdot 5616$, the fall for $5 \cdot 4$.

It leares us $8+81 \cdot 3759$, the ascent for $20 \cdot 1$ seconds.

Then $\quad 8481 \cdot 3759 \sqrt{ } 2$ is the ascent at any angle in the time $20 \cdot 1$ seconds.

We now say, as $8481 \cdot 3759 \sqrt{ } 2: 90^{\circ}:: 5773.3029:$ the angle of elevation, which is $28^{\circ} 46^{\prime} 20^{\prime \prime}$. I Ience we find the range 10513.6 feet; or 3504.5 yards. In this manner we have calculated the table $\mathrm{B}$, from which it will appear that with this velocity, 900 feet per second, the angle of elevation for greatest range is $28^{\circ} 32^{\prime} 40^{\prime \prime}$ which throws two feet fiuther than $28^{\circ} 46^{\prime} 20^{\prime \prime}$. We showed, in a letter of the 23rd July last, addressed to the gentlemen of the Institution of Ciril Engineers, that with relocity 1000 the greatest range tras obtained at $28^{\circ} 53^{\prime} 45^{\prime \prime}$, which indicates that the eleration for greatest range will always be about $28^{\circ} 30^{\prime}$ to $29^{\circ}$-.

28. Our limits do not permit of drawing the trajectory for 25.5 seconds time of flight, but a sketch of that for 10 seconds is hererith given.* It shows the height attained in a flight of 10 seconds at $45^{\circ}$ to be 740 feet, as calculated in our paragraph 17, and this after travelling over a horizontal distance of 1135 feet; so that neither is the vertical height quite equal to half what it would havo been if not acted upon by gravity, viz. 765 feet, nor is the horizontal distance of culmination quite equal to three-quarters of the range $11.17 \cdot 5$ feet.

29. We will give one more example of the working of this problem. On the 24th of Norember, 185t, at Shoeburyness, the 10-inch havitzer of $125 \mathrm{crt}$. is recorded to have thrown its shot of $140 \mathrm{lb}$. to a distance of 4800 or 4900 , say 4850 yards, at $30^{\circ}$ elevation, the charge being $16 \mathrm{lbs}$. of powder. The initial velocity is not given; tre will find it from the above data.

In the triangle A B G we have the three angles $30^{\circ}, 60^{\circ}$, and $90^{\circ}$, and

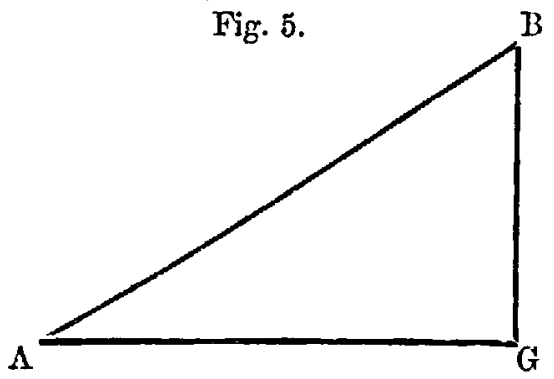
we hare $\perp \mathrm{G}$, the range of 4850 yards or 14,550 feet; we, therefore, casily find

$\mathrm{B} \mathrm{G}=8400.4$ feet and

$A B=16800.8$ feet.

Here $B$ G represents the fall by gravity, and we deduce the time of fliglit from the measure of the fall by gravity. In $24 \cdot 64$ scconds the fall by grarity is $24 \cdot 64^{9} \times 13.836=8400 \cdot 2451456$ feet, therefore, 24.64 seconds

must have been the time of flight.

The report shows incidentally that there was no accurate instrument

* Vide Fig. 8 at pragrapli 17. 
emplosed to measure the true time of flight; mere ocular obseryation is not to be depended upon; we shall assume that $24 \cdot 64$ seconds is the time of falling $8100.4 \mathrm{fect}$, and, therefore, of the range now in question.

30. The next question is to find what relocity would carry a ball from $\Lambda$ to $B, 16800 \cdot 8$ feet, in $24 \cdot 64$ seconds of time, gravity not acting.

We find that 16800.8 divided by the square root of 2 gives us $\frac{16800 \cdot 8}{\sqrt{2}}=11880$, therefore the relocity required to throw a ball vertically uprards 11880 feet in 24.64 seconds of time, if not opposed by grasity, is one of the two equal components of the initial relocity sought.

Now, a ball falling from a height of

$12454 \cdot 7840768$ feet will reach the ground in 30.68 seconds

572.6151936 being passed through in 6.04 seconds, so that

$11882 \cdot 1688832$ fect were passed througl in $24 \cdot 04$ seconds. This is only 2 feet more than we wished. But a ball falling by gravity from a height of feet

$12447 \cdot 6068937$ will reach the ground in $30 \cdot 67$ seconds,

570.7570473 being passed through in 6.03 seconds, so that

11876.8498464 fect were passed through in 24.64 seconds, which is 3 feet less than we wished. Therefore 30.676 is the time in which $a$ ball would, by falling, gain such velocity that in the last $24 \cdot 64$ seconds it should fall through 11880 feet, and the relocity it would thereby have acquired is casily found. From

12454.781 , the fall for 30.68 seconds, deduct

$12447 \cdot 607$, the fall for $30 \cdot 67$, and the differenee, being

$7 \cdot 177$ is the fall in one-limndredth of a second; then

$717 \cdot 7$ is the velocity acquired by falling $30 \cdot 676$ seconds.

31. Then the resultant or equiralent of two equal velocities, one rertical, the other horizontal, each being $\mathbf{7 1 7 . 7}$ feet per second, will be $717 \cdot 7 \sqrt{ } 2$, or 1015 fect, the true initial velocity which rould give a range of 4850 yards at $30^{\circ}$ elevation. And we lave seen that the reltieal or horizontal space passed orer, if not acted on by grarity, would be for $45^{\circ}$ eleration $12451 \cdot 2$ feet, or $4150 \cdot 4$ yards.

32. This agrees tolerably well with our former calculation, that velocity 1000 mould range 3973 yards; it adds 177 yards of range for additional 15 feet of velocity.

33. It is to be regretted that artillery writers should always use such very great velocities in their arguments. It renders impossible any experimental test. Nothing abore a relocity 1100 should erer be taken as matter for argnment; that would be greater velocity than we ever have attained in practice. What is the use of talking of relocity 1250 feet, when it would at $45^{\circ}$ eleration give a range of 5 miles 6 furlongs? Its time of flight would be 53 scconds; the fall by gravity in 53 seconds is $53^{\circ} \times 11=30,899$ feet, or 10,300 yards; therefore the range at $45^{\circ}$ is 10,300 yards, or 5 miles 6 furlongs.

34. We are now in a condition to give a very simple and easy solution of the question which so many liarc called difficult, viz. the measure of the retardation of the ball by the resistance of the atmosphere. The initial relocity of the ball which, when fired vertically upwards, returned to the ground in 25.5 seconds, we hare shom to be $636^{\circ} 13849$ feet per second. If wholly unopposed, this ball would hare gone from $\Lambda$ to $\mathrm{Z}$, 
Fig. 1, a distance equal to $\mathrm{T} \mathrm{V}$, ville paragragh 1 . Hence $\mathrm{T}=\mathbf{2 5} \cdot 5$, and $\mathrm{V}=636 \cdot 13849$; therefore $\mathrm{T} V=16221 \cdot 531496=\Lambda \mathrm{Z}$.

If we deduct 8940.9375 the length of $\Lambda Y$, we find the difference 7280.593995 feet, the length of $\mathrm{Y} Z$, and the measure of the retardation by the resistance of the atmosphere, a ball travelling with velocity 636.13849 fect per second.

35. We have, in paragraph 13 , expressed a doubt whether gumporter can give to iron ball a relocity of $2000 \mathrm{~V}^{2}$; we are by no means sure that it conld give 2000 feet relocity; we are very sure that cast-iron guns are not to be trusted with any velocity approaching that. The 32-pounder gum of 9 fect 7 inches, 63 crt. which burst at Deal in 1837, was only charged with $\frac{375}{1000}$ of its shot's meight; it was giring relocity less than 1000 feet per second when it yielded.

36. It is much to be regretted that all our artillery writers employ such cnormons, such inaginary, relocities, when they adduce examples to illustrate their arguments. Captain Boxer, of the Royal Artillery, supposes an initial velocity of 1774 feet per second, when he means to prove that at $35^{\circ}$ the rauge will be greater than at $45^{\circ}$, and the consequenee is, neither he, nor any one else, can tell what either eleration rould give as range for such velocity. . It is much to be desired, that all should agree on some one relocity, say 1000 feet per second, and let all caleulations hare reference to that.

37. Captain Boxer quotes Hutton for various approximations to the eleration for giring maximum range, as given by Newton, Robius, Euler, and Robinson; and he shows Hntton's calenlation for a 24-pounder, with velocity 1640 feet, which, Hutton sass, would at $34^{\circ} 15^{\prime}$, throw 8336 feet, and this he fixes as tho greatest range which that relocity could give to a 24-pounder ball. It is true Captain Boxer does say that this range is "considerably less than that foumd by experiment," but he does not point ont the fatal error which vitiates the whole of this calculation.

38. Hutton reasoned in the wrong direction, he conld not possibly arrive at the truth. He fixes a theory of terminal relocity, and deduces ranges which erery day's practice proves to be erroneons. Let us put the question as it should be put, reason from the supposed facts, and sce the result. The given facts are the range 8336 feet, and the elevation $34^{\circ} 15^{\prime}$. Required the initial velocity. Hutton nseribes this range and eleration to velocity 1010 feet per second. We shall prore that initinl velocity $829 \cdot 13$ feet per second is the true

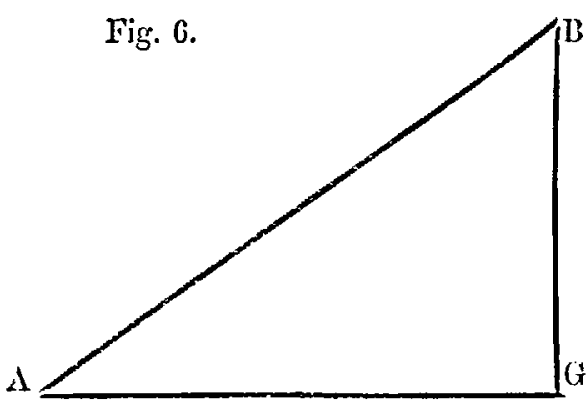

VOL, $\mathbf{v}$ mensure. In the triangle $\Lambda \mathrm{GB}$, let $\lambda \mathrm{G}:$ be the giren range 8336 feet, the angle G I B $31^{\circ} 15^{\prime}$, the angle G B $\Lambda 55^{\circ} 45^{\prime}$, the angle LGA $90^{\circ}$, then the side $B G=5675.78$, and $\triangle \mathrm{B}=1008 . \cdot 8$ feet.

In this triangle $\Lambda \mathrm{G}$ is the rauge, $\mathbf{B} G$ the fall by gravity, $A B$ the ascent, if not deflected by gravity. Then, as the fall by gravity is 
5675.78 feet, we may be sure the time of flight is 19.02 seconds, becare $19.02^{2} \times 14.308=5677.5$ feet, only 1.72 fect orer, and near enough for our purpose.

39. It only remains to show the initial relocity which would earry a ball from $\Lambda$ to $B$ in 19.92 seconls, if not opposed by gravity. $\Lambda$ s it is seen to do this at $34^{\circ}$. $15^{\prime}$, clearly it would do so at $45^{\circ}$ or any other clevation, the resistance of the atmosplecre being the same whaterer angle we fire at; the relocity being the same, the distance traversed will be the same if gravity docs not act. $\Lambda$ t any eleration the relocity may, with adrantage, be considered as the resultant or eqniralent of two relocitics, one of thent vertical, represented by the sine of the angle of eleration; the other horizontal, represented by the eosine of that angle. To calculate radius, let us suppose sine and cosine equal, that is to sny, let us suppose cleration $45^{\circ}$, then the rertical relocity and horizontal relocity eacli will be represented by $v$, and their resultant or equiralent, $v \sqrt{ } 2=\mathrm{V}$, the said $\mathrm{V}$ being the real initial velocity of the ball. Dividing $\Lambda B$ by the square root of 2 , we get the distance $\sigma \cdot \frac{10084}{1+1} \frac{08}{42}=7131.04$ feet, and we sec that this is the vertical height to which, if not opposed by gravity, the rertical velocity $v$ wonld carny the ball in 19.92 seconds.

40. To ascertain what $v$ is, we must see what height a ball must fall from, to ncquire by falling such relocity as to pass through $7131.0 \pm$ fect in the last 19.92 seconds of its fall, and this, though tedious, is not difficult. We find after some few trials that if a ball be suffered to fall ly

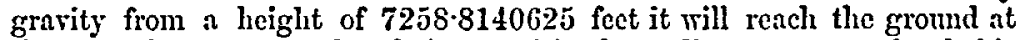
the end of 22.75 seconds of time, and in the carlier 2.83 seconds of this it will have passed through $\left(2.83^{2} \times 16.017\right.$ feet $)=128.27855112$ feet, so that in the remaining 19.92 seconds it would fall through 7130.5355112 feet, only 6 inches short of $7131 \cdot 01$, the desired length, or $\frac{\Lambda \mathrm{B}}{\sqrt{2}}$. The relocity $v$, which a ball acquires by falling $22 \cdot 75$ seconds, is thus found:

$22 \cdot 75^{2} \times 14 \cdot 025=7258 \cdot 8140625$

$22 \cdot 74^{2} \times 14 \cdot 026=7252 \cdot 9511976$

$n$ difiterence of

5.8628619 feet in 0.01 second, showing a velocity, $v$, of 586.28619 fect per second.

41. Then as $(\mathrm{V}=v \sqrt{ } 2)$ the initial velocity, resultant or equivalent of two relocities of $586 \cdot 286+9$ each, is equal to $586 \cdot 286.10 \mathrm{~V} 2$, it is $829 \cdot 13 \pm 3$, as we said in parn. 38 we shoult prove it to be.

42. We subjoin a table, $\mathrm{C}$, by which any artillerist may amuse limself by finding the angle of elevation for any time of flight with this velocity, and we shall gire three examples of 
TABLE A.

Time of Flight 25.5 Scconds. Initial Velocity 636.1385 feet per Second.

\begin{tabular}{|c|c|c|c|c|c|}
\hline \multirow{2}{*}{$\begin{array}{l}\text { Scconds } \\
\text { of } \\
\text { Time. }\end{array}$} & \multicolumn{2}{|c|}{ Vertical Ascent (in fect). } & \multirow{2}{*}{$\begin{array}{c}\text { Fall by Grarity } \\
\text { (iu feet). }\end{array}$} & \multirow{2}{*}{$\begin{array}{l}\text { Actunal licight } \\
\text { attaince in the } \\
\text { whole Time. }\end{array}$} & \multirow{2}{*}{$\begin{array}{l}\text { Space pissed } \\
\text { through in cach } \\
\text { IIalf-Second. }\end{array}$} \\
\hline & Gradual. & Cumulative. & & & \\
\hline $\begin{array}{l}0 \cdot 5 \\
1 \\
1 \cdot 5 \\
2 \\
2 \cdot 5 \\
3 \\
3 \cdot 5 \\
4 \\
4 \cdot 5 \\
5 \\
5 \cdot 5 \\
6 \\
6 \cdot 5 \\
7 \\
7 \cdot 5 \\
8 \\
8 \cdot 5 \\
9 \\
9 \cdot 5 \\
10 \\
10 \cdot 5 \\
11 \\
11 \cdot 5 \\
12 \\
12 \cdot 5 \\
12 \cdot 75 \\
13 \\
13 \cdot 5 \\
14 \\
14 \cdot 5 \\
15 \\
15 \cdot 5 \\
16 \\
16 \cdot 5 \\
17 \\
17 \cdot 5 \\
18 \\
18 \cdot 5 \\
19 \\
19 \cdot 5 \\
20 \\
20 \cdot 5 \\
21 \\
21 \cdot 5 \\
22 \\
22 \cdot 5 \\
23 \\
23 \cdot 5 \\
21 \\
21 \cdot 5 \\
25 \\
25 \cdot 5\end{array}$ & $\begin{array}{c}315 \cdot 9375 \\
311 \cdot 5375 \\
307 \cdot 0625 \\
302 \cdot 5125 \\
297 \cdot 8875 \\
293 \cdot 1875 \\
238 \cdot 1125 \\
283 \cdot 5625 \\
278 \cdot 6375 \\
273 \cdot 6375 \\
268 \cdot 5625 \\
263 \cdot 4125 \\
258 \cdot 1875 \\
252 \cdot 8375 \\
247 \cdot 5125 \\
242 \cdot 0625 \\
236 \cdot 5375 \\
230 \cdot 9375 \\
225 \cdot 2625 \\
219 \cdot 5125 \\
213 \cdot 6375 \\
217 \cdot 7875 \\
201 \cdot 8125 \\
195 \cdot 7625 \\
189 \cdot 6375 \\
92 \cdot 4984375 \\
90 \cdot 9390625 \\
177 \cdot 1625 \\
170 \cdot 8125 \\
164 \cdot 3875 \\
157 \cdot 8875 \\
151 \cdot 3125 \\
144 \cdot 6625 \\
137 \cdot 9375 \\
131 \cdot 1375 \\
124 \cdot 2625 \\
117 \cdot 3125 \\
110 \cdot 2375 \\
103 \cdot 1875 \\
96 \cdot 0125 \\
88 \cdot 7625 \\
81 \cdot 1375 \\
74 \cdot 0375 \\
66 \cdot 5625 \\
59 \cdot 0125 \\
51 \cdot 3375 \\
43 \cdot 6575 \\
35 \cdot 9125 \\
23 \cdot 0625 \\
20 \cdot 1375 \\
12 \cdot 1375 \\
4 \cdot 0625 \\
\end{array}$ & $\begin{array}{l}315 \cdot 9375 \\
627 \cdot 475 \\
934 \cdot 5375 \\
1237 \cdot 05 \\
1534 \cdot 9375 \\
1828 \cdot 125 \\
2116 \cdot 5375 \\
2400 \cdot 1 \\
2678 \cdot 7375 \\
2952 \cdot 375 \\
3220 \cdot 9375 \\
3184 \cdot 35 \\
3742 \cdot 5375 \\
3995 \cdot 425 \\
4242 \cdot 9375 \\
4485 \cdot \\
4721 \cdot 5375 \\
4952 \cdot 475 \\
5177 \cdot 7375 \\
5397 \cdot 25 \\
5610 \cdot 9375 \\
5818 \cdot 725 \\
6020 \cdot 5375 \\
6216 \cdot 3 \\
6405 \cdot 9375 \\
6498 \cdot 4359375 \\
6589 \cdot 375 \\
6706 \cdot 5375 \\
6937 \cdot 35 \\
7101 \cdot 7375 \\
7259 \cdot 625 \\
7410 \cdot 9375 \\
7555 \cdot 6 \\
7693 \cdot 5375 \\
7824 \cdot 675 \\
7948 \cdot 9375 \\
8066 \cdot 25 \\
8176 \cdot 5375 \\
8279 \cdot 725 \\
8375 \cdot 7375 \\
8464 \cdot 5 \\
8545 \cdot 9375 \\
8010 \cdot 975 \\
8686 \cdot 5375 \\
8745 \cdot 55 \\
8796 \cdot 9375 \\
8540 \cdot 625 \\
8576 \cdot 5375 \\
8904 \cdot 6 \\
8924 \cdot 7375 \\
8936 \cdot 875 \\
8940 \cdot 9375 \\
\end{array}$ & $\begin{array}{l}4 \cdot 0625 \\
16 \cdot 2 \\
36 \cdot 3375 \\
64 \cdot 4 \\
100 \cdot 3125 \\
144 \cdot \\
195 \cdot 3875 \\
254 \cdot 4 \\
320 \cdot 9625 \\
395 \cdot \\
476 \cdot 4375 \\
565 \cdot 2 \\
661 \cdot 2125 \\
764 \cdot 4 \\
874 \cdot 6875 \\
992 \cdot \\
1116 \cdot 2625 \\
1247 \cdot 4 \\
1385 \cdot 3375 \\
1530 \cdot \\
1681 \cdot 3125 \\
1839 \cdot 2 \\
2003 \cdot 5875 \\
2174 \cdot 4 \\
2351 \cdot 5625 \\
2442 \cdot 5015625 \\
2535 \cdot \\
2724 \cdot 6375 \\
2920 \cdot 4 \\
3122 \cdot 2125 \\
3330 \cdot \\
3543 \cdot 6875 \\
3763 \cdot 2 \\
3988 \cdot 4625 \\
4219 \cdot 4 \\
4455 \cdot 9375 \\
4698 \cdot \\
4945 \cdot 5125 \\
5198 \cdot 4 \\
5456 \cdot 5875 \\
5720 \cdot \\
5988 \cdot 5625 \\
6262 \cdot 2 \\
6540 \cdot 8375 \\
6824 \cdot 4 \\
7112 \cdot 8125 \\
7406 \cdot \\
7703 \cdot 8575 \\
8006 \cdot 4 \\
8313 \cdot 1625 \\
8625 \cdot \\
8940 \cdot 9375 \\
\end{array}$ & $\begin{array}{l}311 \cdot 875 \\
611 \cdot 275 \\
899 \cdot 2 \\
1172 \cdot 65 \\
1431 \cdot 625 \\
1684 \cdot 125 \\
1921 \cdot 15 \\
21457 \\
2357 \cdot 775 \\
2557 \cdot 375 \\
274 \cdot 5 \\
2919 \cdot 15 \\
3081 \cdot 325 \\
3231 \cdot 025 \\
3368 \cdot 25 \\
3193 \cdot \\
3605 \cdot 275 \\
3705 \cdot 075 \\
3792 \cdot 4 \\
3367 \cdot 25 \\
3929 \cdot 625 \\
3979 \cdot 525 \\
4016 \cdot 95 \\
4041 \cdot 9 \\
4054 \cdot 375 \\
4055 \cdot 031375 \\
4054 \cdot 375 \\
4041 \cdot 9 \\
4016 \cdot 95 \\
3970 \cdot 525 \\
3929 \cdot 625 \\
3867 \cdot 25 \\
3792 \cdot 1 \\
3705 \cdot 075 \\
3605 \cdot 275 \\
3493 \cdot \\
3365 \cdot 25 \\
3231 \cdot 025 \\
3031 \cdot 325 \\
2919 \cdot 15 \\
2744 \cdot 5 \\
2557 \cdot 375 \\
2357 \cdot 75 \\
2145 \cdot 7 \\
1921 \cdot 15 \\
1684 \cdot 125 \\
1434 \cdot 625 \\
1172 \cdot 65 \\
893 \cdot 2 \\
611 \cdot 275 \\
311 \cdot 875 \\
0 \cdot 0 \\
\end{array}$ & $\begin{array}{l}311 \cdot 875 \\
299 \cdot 4 \\
286 \cdot 925 \\
274 \cdot 45 \\
201 \cdot 975 \\
249 \cdot 5 \\
237 \cdot 025 \\
224 \cdot 55 \\
212 \cdot 075 \\
109 \cdot 6 \\
187 \cdot 125 \\
174 \cdot 65 \\
162 \cdot 175 \\
149 \cdot 7 \\
137 \cdot 225 \\
124 \cdot 75 \\
112 \cdot 275 \\
99 \cdot 8 \\
87 \cdot 325 \\
74 \cdot 85 \\
62 \cdot 375 \\
49 \cdot 9 \\
37 \cdot 425 \\
24 \cdot 95 \\
12 \cdot 475 \\
1 \cdot 559375 \\
1 \cdot 559375 \\
12 \cdot 475 \\
24 \cdot 95 \\
37 \cdot 425 \\
49 \cdot 9 \\
62 \cdot 375 \\
74 \cdot 85 \\
87 \cdot 325 \\
99 \cdot 8 \\
112 \cdot 275 \\
124 \cdot 75 \\
137 \cdot 225 \\
149 \cdot 7 \\
162 \cdot 175 \\
174 \cdot 65 \\
187 \cdot 125 \\
199 \cdot 6 \\
212 \cdot 075 \\
224 \cdot 55 \\
237 \cdot 025 \\
249 \cdot 5 \\
261 \cdot 975 \\
274 \cdot 45 \\
256 \cdot 925 \\
299 \cdot 4 \\
311 \cdot 875 \\
\end{array}$ \\
\hline
\end{tabular}


TABLE: $\mathrm{B}$.

Initial Velocity $636 \cdot 1385 \sqrt{ } / 2=399 \cdot 6357$.

\begin{tabular}{|c|c|c|c|c|}
\hline \multirow{2}{*}{$\begin{array}{l}\text { Time } \\
\text { of } \\
\text { Flight. }\end{array}$} & \multirow{2}{*}{ Eleration. } & \multicolumn{2}{|c|}{ Range. } & \multirow{2}{*}{$\begin{array}{l}\text { Logm. Sine of } \\
\text { Eleration. }\end{array}$} \\
\hline & & Fect. & Tards. & \\
\hline $\begin{array}{c}1 \\
2 \\
3 \\
4 \\
5 \\
6 \\
7 \\
8 \\
9 \\
10 \\
11 \\
12 \\
13 \\
14 \\
15 \\
10 \\
17 \\
18 \\
19 \\
20 \\
21 \\
22 \\
23 \\
24 \\
25 \\
25.5\end{array}$ & $\begin{array}{rl}10 & 2 \cdot 18 \\
2 & 6 \cdot 20 \\
3 & 11 \cdot 30 \\
4 & 18 \\
5 & 25 \cdot 50 \\
6 & 35 \\
7 & 46 \cdot 30 \\
9 & \\
10 & 15 \cdot 30 \\
11 & 31 \\
12 & 55 \\
14 & 19 \cdot 12 \\
15 & 47 \\
17 & 24 \\
18 & 55 \\
20 & 37 \cdot 20 \\
22 & 24 \\
24 & 19 \cdot 30 \\
26 & 21 \cdot 30 \\
29 & 32 \cdot 40 \\
30 & 54 \\
33 & 29 \\
36 & 19 \cdot 30 \\
39 & 28 \cdot 40 \\
43 & 2 \\
45 & \\
50 & \\
55 & \\
60 & \\
65 & \\
70 & 75 \\
50 & \\
85 & \\
90 & \end{array}$ & $\begin{array}{c}857 \cdot 3 \\
1749 \\
2581 \\
3334 \cdot 5 \\
4156 \\
4895 \\
5598 \cdot 5 \\
6204 \cdot 7 \\
6859 \\
7478 \\
8021 \\
8518 \\
8967 \\
9366 \cdot 5 \\
9711 \cdot 7 \\
10000 \cdot 6 \\
10229 \cdot 6 \\
10391 \\
10492 \\
10515 \cdot 6 \\
10459 \cdot 1 \\
10314 \\
10072 \cdot 9 \\
9720 \\
9238 \cdot 2 \\
8941 \\
8127 \cdot 6 \\
7252 \cdot 5 \\
6322 \cdot 2 \\
5343 \cdot 7 \\
4324 \cdot 6 \\
3272 \cdot 6 \\
2195 \cdot 6 \\
1102 \\
0\end{array}$ & $\begin{array}{c}296 \\
583 \\
860 \\
1128 \\
1385 \\
1632 \\
1866 \\
20 \$ 3 \\
9290 \\
2493 \\
2674 \\
2339 \\
2989 \\
3122 \\
3237 \\
3333 \cdot 5 \\
3110 \\
3463 \\
3497 \\
3505 \cdot 2 \\
3186 \cdot 7 \\
3438 \\
3357 \cdot 6 \\
3210 \\
3079 \cdot 4 \\
2980 \cdot 3 \\
2709 \cdot 2 \\
2417 \cdot 5 \\
2107 \cdot 1 \\
1781 \cdot 2 \\
1441 \cdot 5 \\
1091 \\
732 \\
367 \\
0\end{array}$ & $\begin{array}{r}8.2614035 \\
5659836 \\
7453417 \\
8747723 \\
9759105 \\
9 \cdot 0595654 \\
1312426 \\
1942343 \\
2506685 \\
3021649 \\
3492624 \\
3932924 \\
4346188 \\
4757400 \\
5110150 \\
5467733 \\
5812694 \\
6148063 \\
6473401 \\
6782848 \\
7107053 \\
7417624 \\
7725857 \\
8033079 \\
8340584 \\
8494850\end{array}$ \\
\hline
\end{tabular}


TABLE C.

Time of Flight 22.75 Seconds, Initial Velocity $586 \cdot 2865$ feet per Second.

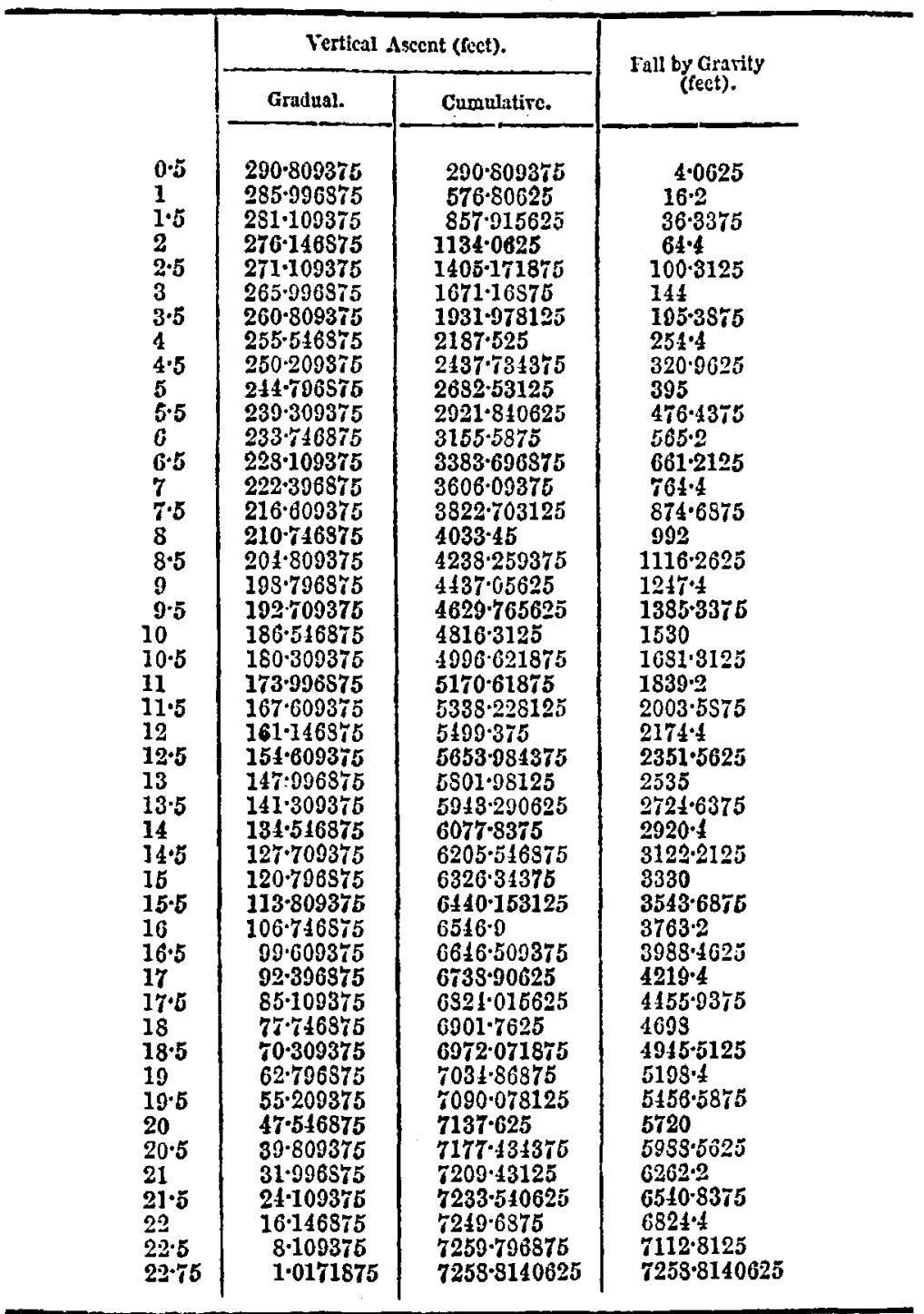

